\title{
Erasmus syndrome with pulmonary tuberculosis
}

\author{
Abhishek Goyal, Karan Madan, Navneet Singh
}

Department of Pulmonary Medicine, Postgraduate Institute of Medical Education \& Research (PGIMER), Chandigarh, India

\section{Correspondence to}

Dr Navneet Singh, navneetchd@hotmail.com
To cite: Goyal A, Madan K, Singh N. BMJ Case Rep Published online: [please include Day Month Year] doi:10.1136/bcr-2013010443

\section{DESCRIPTION}

A 60-year-old male patient presented with a history of shortness of breath for 4 months and low-grade fever for 1 month. He had developed progressive skin tightening predominantly over the extremities and Raynaud's phenomenon for the last 6 months. The patient was a chronic smoker and used to work as a manual labourer with nearly a 35 -year history of unprotected exposure to cement dust. On examination, there was thickening of skin over the hands, face and trunk (figure 1, left panel). Skin examination demonstrated 'salt and pepper dermopathy' (figure 1 right panel).

CT scan of the thorax demonstrated small calcified mediastinal lymph nodes (figure 2 left panel) and a thin-walled cavity with surrounding nodules in the right lung upper lobe (figure 2 middle panel). Radiographs of the hand demonstrated calcinosis cutis (figure 2 right panel). Antinuclear antibody titers were elevated and sputum smear examination was positive for acid-fast bacilli. A final diagnosis of Erasmus syndrome (diffuse cutaneous systemic sclerosis with silica exposure) and sputum smear-positive pulmonary tuberculosis was made.

The Erasmus syndrome describes the association of generalised progressive systemic sclerosis following exposure to silica with or without silicosis. ${ }^{1}$ Our patient had a strong history of silica exposure from cement dust and radiological signs in the form of mediastinal lymph node calcification. Silica exposure is a strong risk factor for the development of systemic sclerosis, and the features of silica associated systemic sclerosis are clinically, serologically and immunologically indistinguishable from idiopathic scleroderma. ${ }^{2}$ Also, silica exposure even without silicosis is a strong risk factor for the development of pulmonary tuberculosis. To the best of our knowledge, this is the first case report of coexistence of Erasmus syndrome with active pulmonary tuberculosis.
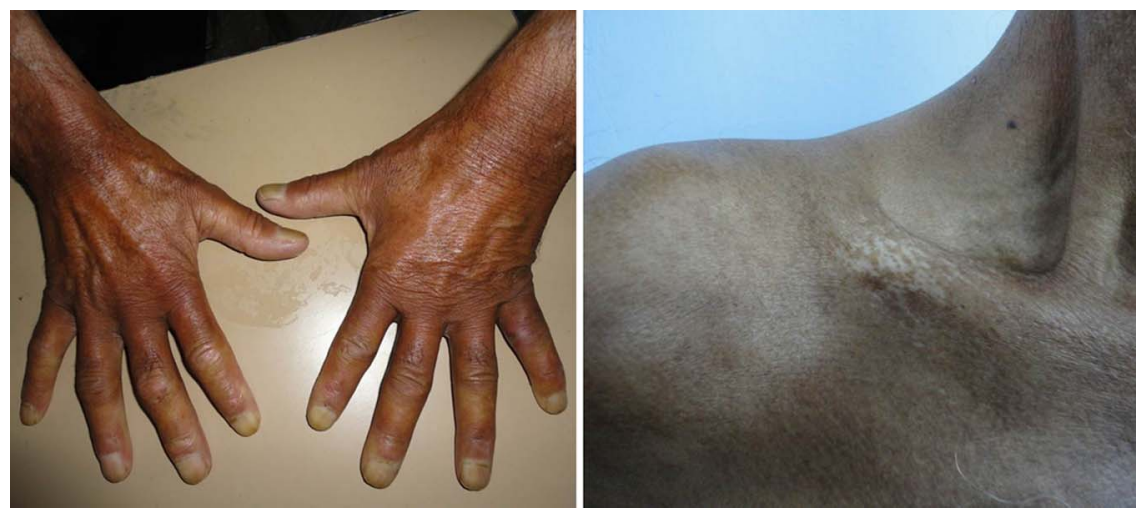

Figure 1 (Left panel) Clinical photograph depicting tightening of skin of both the hands. (Right panel) Salt and peer dermopathy changes are seen over the anterior chest.
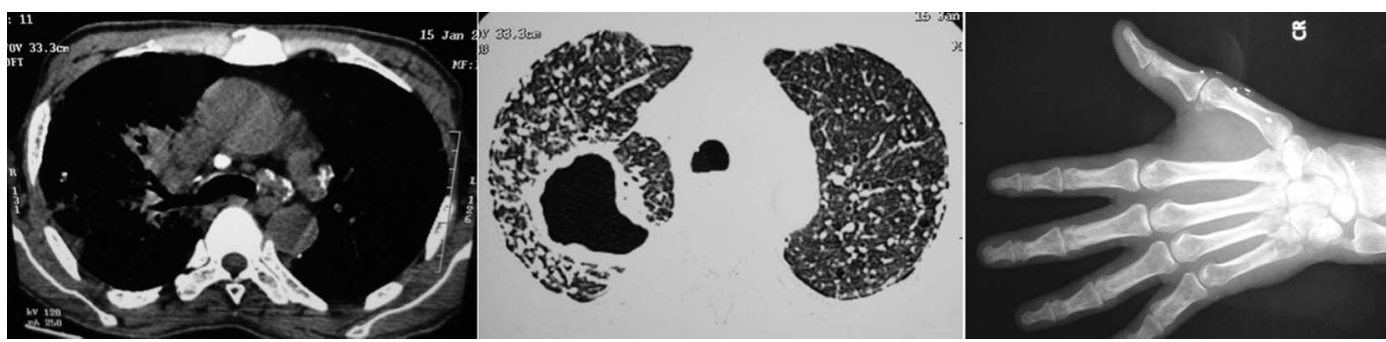

Figure 2 (Left panel) CT scan of the thorax (mediastinal window section) demonstrating calcification in mediastinal lymph nodes. (Middle panel) CT scan of the thorax lung window sections demonstrating a thin-walled cavity with surrounding nodules in right upper lobe. (Right panel) Hand X-ray depicting calcification in the skin suggestive of calcinosis cutis. 


\section{Learning points}

- Erasmus syndrome refers to the presence of generalised progressive systemic sclerosis following silica exposure, with or without silicosis.

- Patients with silica exposure are at high risk for the development of pulmonary tuberculosis, and the risk can persist even following the cessation of exposure.
Competing interests None.

Patient consent Obtained.

Provenance and peer review Not commissioned; externally peer reviewed.

\section{REFERENCES}

1 Chaouch N, Mjid M, Zarrouk M, et al. [Erasmus' syndrome with pseudo-tumour masses]. Rev Mal Respir 2011;28:924-7. Un syndrome d'Erasmus avec des masses pseudo-tumorales.

2 Rustin MH, Bull HA, Ziegler V, et al. Silica-associated systemic sclerosis is clinically, serologically and immunologically indistinguishable from idiopathic systemic sclerosis. Br J Dermatol 1990;123:725-34.

Copyright 2013 BMJ Publishing Group. All rights reserved. For permission to reuse any of this content visit http://group.bmj.com/group/rights-licensing/permissions.

BMJ Case Report Fellows may re-use this article for personal use and teaching without any further permission.

Become a Fellow of BMJ Case Reports today and you can:

- Submit as many cases as you like

- Enjoy fast sympathetic peer review and rapid publication of accepted articles

- Access all the published articles

- Re-use any of the published material for personal use and teaching without further permission

For information on Institutional Fellowships contact consortiasales@bmjgroup.com

Visit casereports.bmj.com for more articles like this and to become a Fellow 